\title{
THE INFECTIVITY OF SFMNPV ON FALL ARMYWORM IS INFLUENCED BY THE HOST PLANT
}

\author{
IGOR HENRIQUE SENA DA SILVA ${ }^{1}$, VICTOR HUGO DUARTE DA COSTA ${ }^{2}$, \\ JULIANO DE CARVALHO CURY ${ }^{3}$, FERNANDO HERCOS VALICENTE ${ }^{4}$ \\ and RICARDO ANTONIO POLANCZYK ${ }^{1}$
}

\author{
${ }^{1}$ Universidade Estadual Paulista “Júlio de Mesquita Filho”, Faculdade de Ciências Agrárias e Veterinárias, \\ igor.sena@outlook.com.br,rapolanc@fcav.br; \\ ${ }^{2}$ Universidade Federal de Lavras, vitorhugodc@yahoo.com.br; \\ ${ }^{3}$ Universidade Federal de São João Del Rei, jccury@ufsj.br; \\ ${ }^{4}$ Embrapa Milho e Sorgo, fernando.valicente@embrapa.br
}

Revista Brasileira de Milho e Sorgo, v.17, n.3, p. 369-379, 2018

\begin{abstract}
This work evaluated the infectivity and production of occlusion bodies (OBs) of the SfMNPV-6NR on fall armyworm (FAW), Spodoptera frugiperda, when fed on different host plants. The experiment was performed in laboratory, in a completely randomized design using two concentrations of SfMNPV-6NR $\left(2 \times 10^{6}\right.$ and $\left.2 \times 10^{7} \mathrm{OBs} / \mathrm{mL}\right)$ and six different host plants (soybean, corn, cotton, bean, sorghum and millet). The larval mortality, larval weight (LW), pupal weight (PW) of $S$. frugiperda and the production of OBs by virus were evaluated. S. frugiperda larvae were less susceptible to baculovirus when fed on cotton leaves ( $38 \pm 4.17$ and $70 \pm 6.44 \%$ mortality) in the two concentrations tested $\left(2 \times 10^{6}\right.$ and $2 \times 10^{7} \mathrm{OBs} / \mathrm{mL}$, respectively). The LW was affected by the virus concentration depending on the plant species consumed and the virus concentrations. The PW was affected by the plant species used to feed larvae. There was no effect of the host plant on the OBs virus production. The results demonstrate adverse effects of the host plant on the infectivity of the SfMNPV-6NR in S. frugiperda, especially a deleterious effect of the cotton plant in the virus infection capacity.
\end{abstract}

Keywords: Fall armyworm; entomopathogenic virus; tritrophic interaction; plant host; cotton.

\section{A INFECTIVIDADE DE SFMNPV SOBRE A LAGARTA-DO-CARTUCHO É INFLUENCIADA PELA PLANTA HOSPEDEIRA}

\begin{abstract}
RESUMO - Este trabalho avaliou a capacidade de infecção e produção de corpos de oclusão (CO) de SfMNPV6NR sobre a lagarta-do-cartucho, Spodoptera frugiperda, quando alimentada em diferentes plantas hospedeiras. O experimento foi realizado em laboratório, em delineamento inteiramente casualizado, utilizando duas concentrações de SfMNPV-6NR $\left(2 \times 10^{6}\right.$ e $\left.2 \times 10^{7} \mathrm{CO} / \mathrm{mL}\right)$ e seis diferentes plantas hospedeiras (soja, milho, algodão, feijão, sorgo e milheto). Foram avaliados a mortalidade larval, o peso de larvas mortas (PL), o peso de pupa (PP) e a produção de $\mathrm{CO}$ do vírus. As larvas de $S$. frugiperda foram menos suscetíveis ao baculovírus quando alimentadas com folhas de algodão, apresentando as menores taxas de mortalidade (38 $\pm 4,17$ e $70 \pm 6,44 \%)$ com as duas concentrações testadas $\left(2 \times 10^{6}\right.$ e $2 \times 10^{7} \mathrm{CO} / \mathrm{mL}$, respectivamente). O PL foi afetado pela concentração de vírus, dependendo da espécie de planta consumida e concentração de vírus testada. O PP foi afetado pela espécie de planta com a qual as larvas foram alimentadas. Não houve efeito da planta hospedeira na produção de CO do vírus. Nossos resultados demonstram um efeito adverso da planta hospedeira sobre a inefetividade do vírus em $S$. frugiperda, especialmente um efeito deletério da planta de algodão na capacidade de infecção do vírus.
\end{abstract}

Palavras-chave: lagarta-do-cartucho-do-milho, vírus entomopatogênico, interação tritrófica, planta hospedeira, algodão.

Versão on line ISSN 1980-6477 - http://www.abms.org.br 
The fall armyworm, Spodoptera frugiperda (Smith, 1797) (Lepidoptera: Noctuidae) is the most important pest of corn in Brazil, and it is responsible for losses of about US\$ 400 million per year in this country (Rosa \& Barcelos, 2012). S. frugiperda is a highly polyphagous pest that feeds in more than 80 plant species, among them important crops such as soybean, sorghum, millet, bean, cotton and Solanaceae (Cruz et al., 2010).

Among the biological control agents, viruses are a viable alternative for pest control, especially those from the baculovirus group, and are a fundamental tool in the context of Integrated Pest Management (IPM). The Baculoviridae family is host specific restricted to arthropods and are organized into four genera: Alphabaculovirus, lepidopteran-specific nucleopolyhedrovirus (NPV); Betabaculovirus, lepidopteran-specific granulovirus (GV); Gammabaculovirus, hymenopteran-specific nucleopolyhedrovirus and Deltabaculovirus, dipteranspecific nucleopolyhedrovirus. The NPV and GV genera act initially in the midgut of the insects and present cell infection in all tissues of the host insect (Herniou et al., 2012).

Among the NPV, Spodoptera frugipeda multiple nucleopolyhedrovirus (SfMNPV) is an alternative for the IPM of $S$. frugiperda due its high specificity, environmental safety and high level of virulence (Grzywacz, 2017). Infection starts when a baculovirus occlusion body (OB) ingested with contaminated food starts a new infectious cycle. When OBs pass through the foregut and reach the alkaline midgut the proteinaceous matrix is dissolved releasing occlusion derived virus (ODV). Virus degrades the peritrophic membrane and host encoded enzymes present in the OB, allowing the ODV to enter the cell. ODV enters the cell by fusion with epithelial cell microvilli releasing nucleocapsids (NC) into the cytoplasm. NC may enter the nucleus, disassemble and release the genome (adapted from Adams \& McClintock, 1991).

The action of the baculoviruses is slower than chemical insecticides, taking more time to kill the target insect. Although a baculovirus-contaminated larvae reduced its feed by $93 \%$ (Valicente, 1988), this insect still feeds on the sprayed plant for a couple of days, until it drastically reduces feeding.

Host plants can modulate interactions between insect herbivores and their pathogens. Inter and intraspecific differences in plant chemistry and structure can alter the susceptibility of insects to infection and the production and environmental persistence of pathogens (Cory \& Hoover, 2006). Thus, several studies were performed using different combinations of tritrophic interactions (plant-insectbaculovirus), and significant differences were reported in susceptibility of insect to baculovirus, such as in the pathogenicity, virulence or OBs production (Roode et al., 2008; Ravishankar \& Venkatesha, 2010).

In 2017, the first spray formulated to fall armyworm control was registered in Brazil with an isolate from SfMNPV (CartuchoVIT ${ }^{\circledR}$ ) as active ingredient (Brasil, 2013). Isolate 6 from the Baculovirus Collection of Embrapa Milho e Sorgo presents a unique characteristic of not causing liquefaction of the integument immediately after larvae death. Sequencing of the chitinase A (v-chiA) gene from this isolate (SfMNPV-6) showed a mutation in the gene that generates a premature stop codon, considerably reducing the size of the putative enzyme (Vieira et al., 2012). However, fall armyworm is a highly polyphagous pest and other biologic control companies have developed biopesticides based on SfMNPV-6 NR strain. Thus, the evaluation of the 
efficiency of SfMNPV-6NR in different host plants is necessary. The objective of this work was to evaluate the infectivity and OBs production of SfMNPV-6NR in $S$. frugiperda in soybean, bean, maize, sorghum, millet and cotton.

\section{Material and Methods}

The experiments were conducted in the Biological Control Laboratory of Embrapa Milho e Sorgo, Sete Lagoas, State of Minas Gerais, Brazil. The experimental design was completely randomized composed of twelve treatments resulting from the combination of six different plant species (soybean, maize, cotton, bean, sorghum and millet) and two virus concentrations $\left(2 \times 10^{6}\right.$ and $\left.2 \times 10^{7} \mathrm{OBs} / \mathrm{mL}\right)$. A control treatment was performed spraying only distilled water and Tween $20^{\circledR}$ in plants. Each treatment consisted of four replications with $24 S$. frugiperda second instar larvae, totaling 96 larvae per treatment.

The plants were cultivated in $0.70 \mathrm{~m}$ spacing between lines and fertilized with $400 \mathrm{~kg} / \mathrm{ha}$ of NPK (00-30-16) $+0.3 \%$ of $\mathrm{Zn}$. The cultivars used were BRS 1501 (millet), DKB390 (maize), BRS 308 (sorghum), Pérola (bean), BRS Valiosa RR (soybean) and BRS 368RF (cotton). After the emergence of the plants, a coating fertilization was performed with $200 \mathrm{~kg} / \mathrm{ha}$ of Urea. Twenty plants of each species were collected 15 days after planting. Leaves were washed with sodium hypochlorite $(0.5 \%)$ and rinsed with distilled water.

A $S$. frugiperda colony was maintained at 25 $\pm 2{ }^{\circ} \mathrm{C}, 65-80 \%$ relative humidity (RH) and 14 hours of photoperiod. Larvae were grown on artificial diet (Greene et al., 1976). All experiments were conducted under the same conditions of photoperiod and $\mathrm{RH}$. The first SfMNPV-6NR isolate was obtained from a natural epizootic in a field population of $S$. frugiperda collected in Paraná State, Brazil, and multiplication of this isolate was done using healthy larvae from the artificial rearing

Dead larvae were daily collected and stored at $-18^{\circ} \mathrm{C}$ for purification of the OBs. The dead larvae were macerated in TE buffer $\mathrm{pH} 8.0(10 \mathrm{~mL} / \mathrm{L} 0.1 \mathrm{M}$ Tris- $\mathrm{HCl}$ and $2 \mathrm{~mL} / \mathrm{L}$ 0.5 M EDTA). This suspension was filtered through a layer of cheesecloth, and the filtrate was centrifuged twice at $11,952 \mathrm{~g}$ during 15 min. The resulting pellet was resuspended in $2 \mathrm{~mL}$ of sterile distilled water, layered onto a 19.5, 18.75, 18.0 and $17.9 \mathrm{~g} / 15 \mathrm{~mL}$ sucrose gradient, followed by centrifugation at $103,70 \mathrm{~g} / 4{ }^{\circ} \mathrm{C}$ during $40 \mathrm{~min}$. The viral band was collected followed by another centrifugation in buffer at 11,952 g during $15 \mathrm{~min}$. The pellet was suspended in sterile distilled water, and the virus suspension was stored at $-18^{\circ} \mathrm{C}$. In order to determine the virus concentrations, serial dilutions until $10^{-4}$ were performed. The number of OBs was quantified using a Neubauer hemocytometer.

The leaves were cut in $3 \mathrm{~cm}^{2}$ discs that were submerged in a SfMNPV-6NR suspension with the two pre-established virus concentrations $\left(2 \times 10^{6}\right.$ and $\left.2 \times 10^{7} \mathrm{OBs} / \mathrm{mL}\right)+50 \mu \mathrm{L}$ of Tween $20^{\circledR}$ (Merck Schuchardt, Germany). In check treatment, leaves were submerged in distilled water $+50 \mu \mathrm{L}$ of Tween $20^{\circledR}$. Then, the leaves were transferred to six trays containing 16 individual cells each. A second instar S. frugiperda larvae was placed in each cell, totaling six replicates with 16 larvae. The larvae were fed for 48 hours at $25 \pm 2{ }^{\circ} \mathrm{C}, 65-80 \%$ of $\mathrm{RH}$ and 14 hours of photoperiod, and transferred to acrylic cups of 50 $\mathrm{mL}$ and fed on artificial diet. Mortality was evaluated 7 days after exposure to the virus. Dead larvae were weighed and stored at $-18{ }^{\circ} \mathrm{C}$ for $\mathrm{OBs}$ production analysis. The surviving larvae were weight when reached pupal stage. In order to quantify OBs 
production, dead larvae were macerated with distilled water and filtered through a cheesecloth. The viral suspensions were transferred to $2 \mathrm{~mL}$ polypropylene microtubes. After serial dilutions of the concentrate, the total number of OBs was quantified using a Neubauer chamber (hemocytometer).

Mortality data were transformed using arcsine and Abbott's formula ( $(\%$ mortality in treatment - \% mortality in control/ 100 - mortality in control) $\times 100$ ) for analysis. Non-transformed means are reported in all figures. Shapiro and Wilk (1965) and Bartlett's test (Bartlett, 1937) were performed to check the normality of residuals and homogeneity of variances, respectively. Mortality, larval weight, pupal weight and OBs production were subjected to ANOVA $(P<$ 0.05 ) followed by post hoc Tukey test when necessary. STATISTICA 7.0 software package was used for all statistical analysis. All data are reported as means \pm standard error.

\section{Results and Discussion}

The larval mortality of the $S$. frugiperda was strongly affected by the host plant in which the larvae were fed $(F=13.86 ; \mathrm{df}=5.36 ; P=<0.001)$, by virus concentration $(F=77.36$; df $=1.36 ; P=0.006)$ and the interaction among these two factors $(F=4.33$; $\mathrm{df}=5.36 ; P=0.004$ ) (Table 1 ). Low mortality of S. frugiperda larvae was recorded when fed cotton leaves contaminated with the two virus concentrations (Figure 1). These results demonstrate the existence of an interference of this plant in the capacity of the baculovirus to infect the insect.

Similar results were obtained by Navon et al. (1988) evaluating the effect of cotton leaves on virus infection in Spodoptera litorallis and Chloridea virescens. Farrar and Ridgway (2000) compared the influence of cotton and tomato leaves contaminated with an Anagrapha falcifera NPV (AfMNPV) on larval survival of Helicoverpa zea and Spodoptera exigua, and reported a higher susceptibility to AfMNPV when fed on tomato leaves compared with cotton leaves. These authors highlighted that this differential susceptibility may be related to the high alkalinity found on the cotton leaf surface $(\mathrm{pH}$ 9-11), which solubilizes the protein matrix of the polyhedra prior to ingestion by the insects, inhibiting their infective capacity. Hoover et al. (2000) reported

Table 1. ANOVA of the effect of the host plants soybean, cotton, millet, maize, bean and sorghum, SfMNPV$6 \mathrm{NR}$ concentration and its interaction on larval mortality, larval weight and pupal weight of $S$. frugiperda and occlusion bodies production of SfMNPV-6NR.

\begin{tabular}{|c|c|c|c|c|c|c|c|c|c|}
\hline \multirow{2}{*}{ Treatment } & \multirow{2}{*}{$\mathrm{df}$} & \multicolumn{2}{|c|}{ Larval mortality } & \multicolumn{2}{|c|}{ Larval weight } & \multicolumn{2}{|c|}{ Pupal weight } & \multicolumn{2}{|c|}{ OBs production } \\
\hline & & $F$ & $P$ & $F$ & $P$ & $F$ & $P$ & $F$ & $P$ \\
\hline Host plant & 5 & 13.8600 & $<0.0001 * *$ & 5.8480 & $0.0013^{*}$ & 10.0790 & $<0.0001 *$ & 0.1790 & $0.9477 \mathrm{~ns}$ \\
\hline $\begin{array}{c}\text { Virus } \\
\text { concentration }\end{array}$ & 1 & 77.3610 & $<0.0001 * *$ & 21.7620 & $<0.0001^{* *}$ & 1.2090 & $0.3064 \mathrm{~ns}$ & 2.3600 & $0.1350 \mathrm{~ns}$ \\
\hline Interaction & 5 & 4.3260 & $0.0035 *$ & 1.9060 & $0.1352 \mathrm{~ns}$ & 7.0150 & $<0.0001 *$ & 0.6210 & $0.6512 \mathrm{~ns}$ \\
\hline
\end{tabular}

*significant $(P<0.05)$

** significant $(P<0.01)$

ns. not significant $(P<0.05)$ 


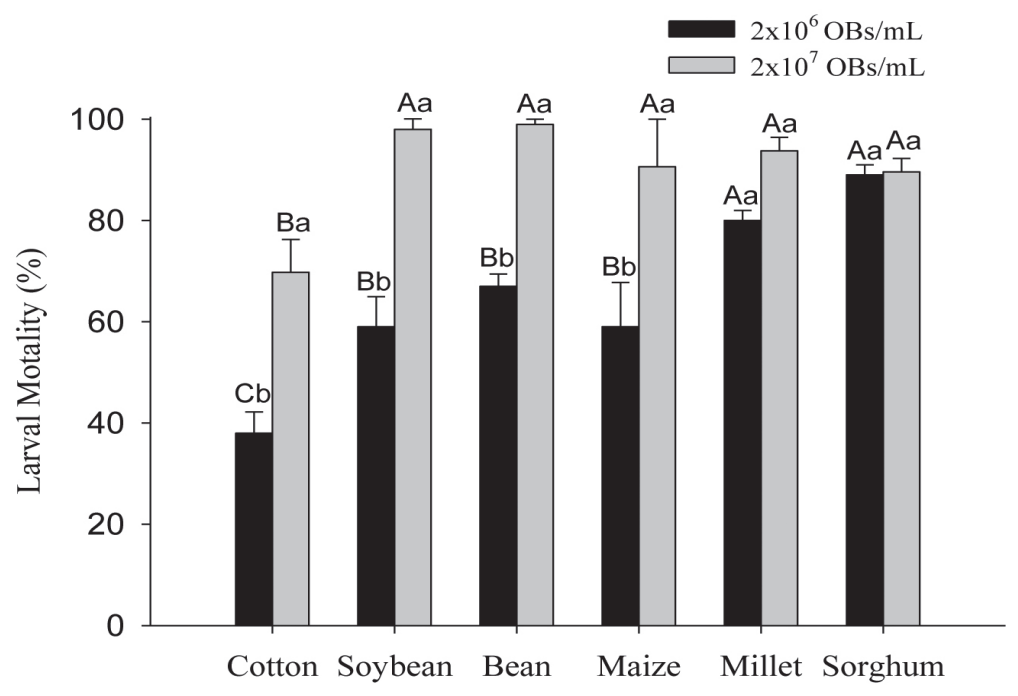

Figure 1. Larval mortality (\%) ( $\pm \mathrm{SE})$ of $S$. frugiperda $2^{\text {nd }}$ instar fed on soybean, bean, corn, millet and sorghum leaves in two concentrations of SfMNPV-6NR $\left(2 \times 10^{6}\right.$ and $\left.2 \times 10^{7} \mathrm{OBs} / \mathrm{mL}\right)$. Columns followed by the same upper and lower-case letters do not differ statistically between host plants and virus concentrations, respectively, by the Tukey test $(P=0.05)$.

low susceptibility of Chloridea virescens larvae to Autographa californica NPV when fed on cotton leaves compared to lettuce leaves. These authors correlated the low susceptibility of $H$. virescens to the high levels of peroxides and condensed tannins on the cotton leaf surface.

Shikano et al. (2017) induced the resistance of eight soybean genotypes and observed that FAW mortality inflicted by baculovirus (SfMNPV) did not vary among soybean genotypes when the virus was ingested with non-induced foliage. Moreover, ingestion of the virus on JA-induced foliage reduced armyworm mortality compared to non-induced foliage in some soybean genotypes and the baculovirus efficacy was lower when ingested with foliage containing higher phenolic content and defensive properties that reduced armyworm weight gain and leaf utilization with the jasmonic acid induced foliage application. As pointed out by other authors (Farrar \& Ridgway, 2000; Hoover et al., 2000), the high amount of secondary compounds in the cotton leaves surface, used as plant defense, can explain the lower efficacy of the baculovirus on the pest. This means that the differential compatibility of plants defense with the third trophic level highlights an important cost/tradeoff associated with plant defense strategies.

Acording to Plymale et al. (2008), differences in diet quality may modify the peritrophic matrix structure of lepidopteran larvae and change the infectivity of baculovirus in the insect midgut. These effects are known as "bottom up", a cascade effect caused by the quality of resource, and can influence the upper trophic levels, herbivores and their natural enemies. The secondary compounds released by the plant may be inactivating the virus prior to ingestion by the insect and preventing the disease triggering. Several factors may explain a low susceptibility of Lepidoptera to a NPV in the cotton crop, including the $\mathrm{pH}$ of leaf surface and phenolic compounds produced by the plant. Furthermore, these factors can 
be acting alone or together and, thus, increasing the insect NPV resistance. However, further chemical studies involving volatiles compounds produced by the plants are necessary to have new insights of this complex relationship.

The larval weight (LW) of $S$. frugiperda was affected by the host plant consumed $(F=5.8480$; df $=4.30 ; P=0.001)$ and the virus concentration $(F=$ 21.76; df $=1.30 ; P=<0.001$ ) inoculated on leaves. However, there was no interaction between these factors $(F=1.9060 ; \mathrm{df}=4.30 ; P=0.135)$ (Table 1$)$. Considering the plants tested, S. frugiperda larvae obtained the highest LW when fed with sorghum or millet $(0.043 \mathrm{~g}$ and $0.037 \mathrm{~g}$, respectively). Otherwise, larvae fed on cotton leaves obtained the lower LW $(0.024 \mathrm{~g})$ (Figure 2). The application of the virus in the concentration of $2 \times 10^{6} \mathrm{OBs} / \mathrm{mL}$ resulted in higher larval weight of $S$. frugiperda $(0.040 \mathrm{~g})$, statistically superior to the LW when compared with the application of the virus concentration of $2 \times 10^{7}$ $\mathrm{OBs} / \mathrm{mL}(0.027 \mathrm{~g})$ (Figure 3).

Valicente et al. (2013), evaluating the LW of $S$. frugiperda fed on maize and castor leaves exposed at 48 and 72 hours to SfMNPV-6NR, observed that only the exposure time to virus affected the weight at death. In the present study, the smaller amount of polyhedra ingested in the lower concentration of virus possibly provided a longer survival time for the larvae when compared with the higher virus concentration, causing a greater weight gain until the death. This factor must be taken into account, because, after the insect death, the integument rupture occurs, and the polyhedra releasing to the environment, and, finally, the horizontal transmission of the virus, which is highly important to pest management in the long-term.

The pupae weight (PW) of $S$. frugiperda was strongly affected by the plant species used to fed larvae $(F=10.08 ; \mathrm{df}=5.54 ; P=<0.001)$ and by the interaction between the two factors $(F=7.02$; df $=10.54 ; P=<0.001)$. There was no effect of virus concentration on $\mathrm{PW}(F=1.21 ; \mathrm{df}=2.54 ; P=0.306)$. Considering the plants tested, S. frugiperda pupae presented PW differentiated when fed on different plant species inoculated with baculovirus compared to the control. The larvae that ingested cotton leaves inoculated with the two concentrations of SfMNPV$6 \mathrm{NR}$ and bean leaves inoculated with $2 \times 10^{7} \mathrm{OBs} /$ $\mathrm{mL}$ presented $\mathrm{PW}$ inferior to the control. Otherwise, $S$. frugiperda larvae fed on maize leaves inoculated with $2 \times 10^{7} \mathrm{OBs} / \mathrm{mL}$ of SfMNPV-6NR obtained PW higher than the control (Figure 4). Piubelli et al. (2009), evaluating the Anticarsia gemmatalis PW fed on two different soybean genotypes containing two AgMNPV concentrations, reported lower PW values in relation to the control. In addition, this difference also occurred among genotypes, indicating that this parameter is affected not only by the host plant, but also by genotype, suggesting genetic variation among them.

There was no effect of the host plant on the OBs production of the SfMNPV-6NR when infecting S. frugiperda (Table 1). Although no statistical difference was observed in the virus production between the host plants and the amount of virus inoculated on the leaves, larvae fed with the lowest concentration of virus produced a greater amount of virus polyhedra, independently of the host plant (Fig. 5). This may be due to the lower concentration of virus inoculated in the leaves that allowed greater survival of the larvae and thus causing the greater production of virus. Otherwise, other studies demonstrated the effect of the host plant in the viral production (Monobrullah et al., 2007; Raymond \& Hails, 2007). The reason for this difference between 


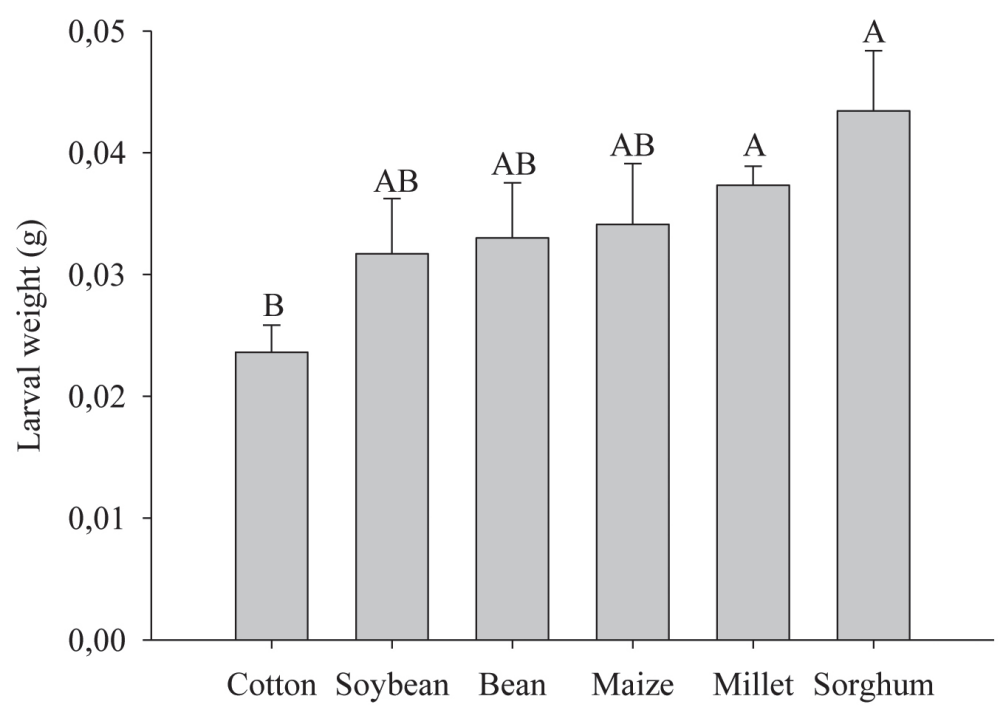

Figure 2. Larval weight of $S$. frugiperda fed on bean, soybean, cotton, corn, sorghum and millet. Mean of two concentrations of SfMNPV-6NR $\left(2 \times 10^{6}\right.$ and $\left.2 \times 10^{7} \mathrm{OBs} / \mathrm{mL}\right)$. Bars followed by the same letter do not differ by Tukey test $(P=0.05)$.

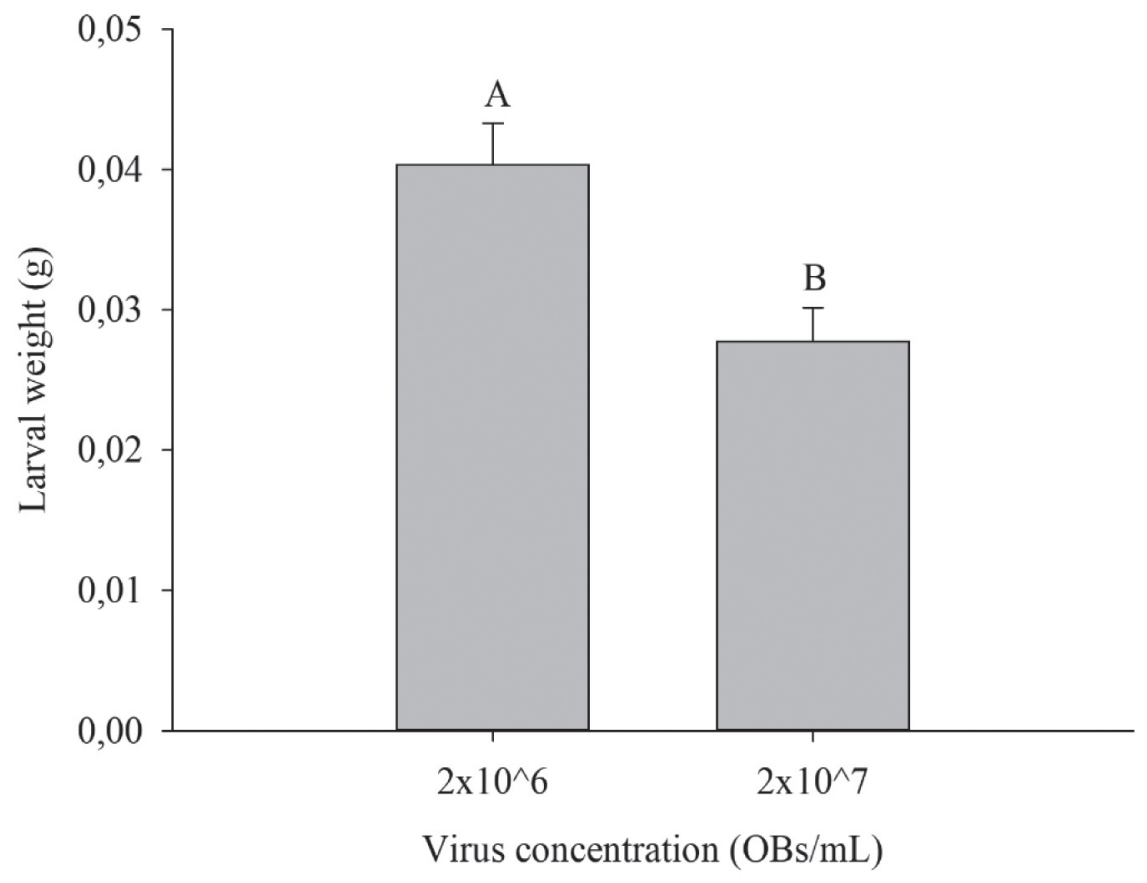

Figure 3. Larval weight of $S$. frugiperda fed with two concentrations of SfMNPV-6NR $\left(2 \times 10^{6}\right.$ and $2 \times 10^{7} \mathrm{OBs} /$ $\mathrm{mL})$. Mean of six host plants: bean, soybean, cotton, corn, sorghum and millet. Bars followed by the same letter do not differ by Tukey test $(P=0.05)$. 
this study and others are unclear, especially because the viral production depends on several factors, such as larval age, speed of the death, aspects of the host plant and the virus physiology (Ravishankar \& Venkatesha, 2010; Valicente et al., 2013; Redman et al., 2016). Indeed, the OBs production of the virus is a key aspect of the insect-pathogen interaction and may have significant implications on the populational dynamics and the virus establishment in the field in the long run.

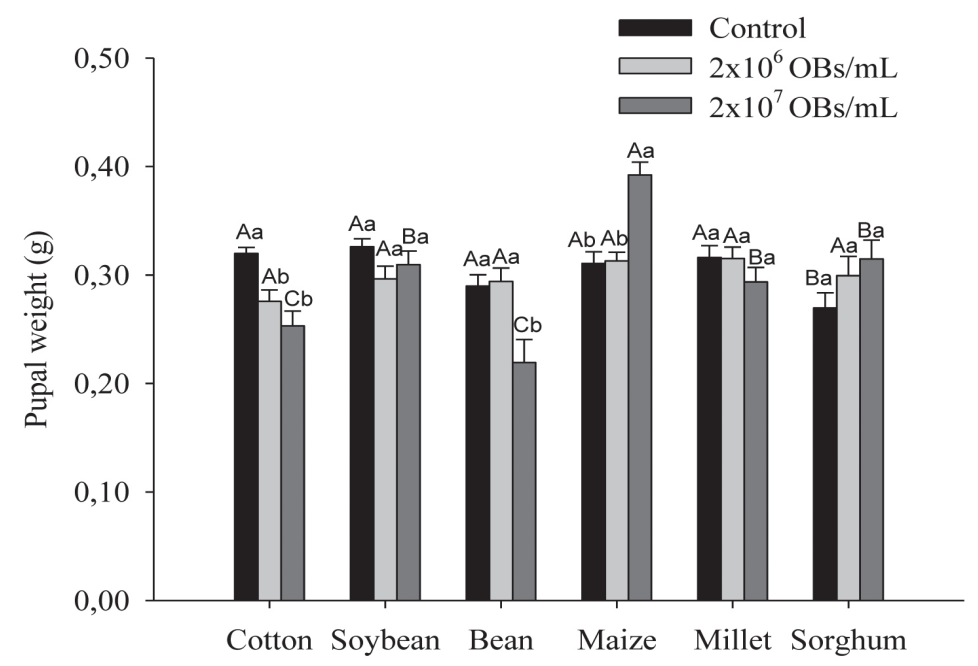

Figure 4. Pupal weight $( \pm \mathrm{SE})$ of $S$. frugiperda fed on six different host plants: soybean, cotton, millet, bean, maize and sorghum, inoculated with two concentrations of SfMNPV-6NR $\left(2 \times 10^{6}\right.$ and $\left.2 \times 10^{7} \mathrm{OBs} / \mathrm{mL}\right)$ and control treatment. Bars followed by the same upper and lower-case letters do not differ among host plants and virus concentrations, respectively, by the Tukey test $(P=0.05)$.

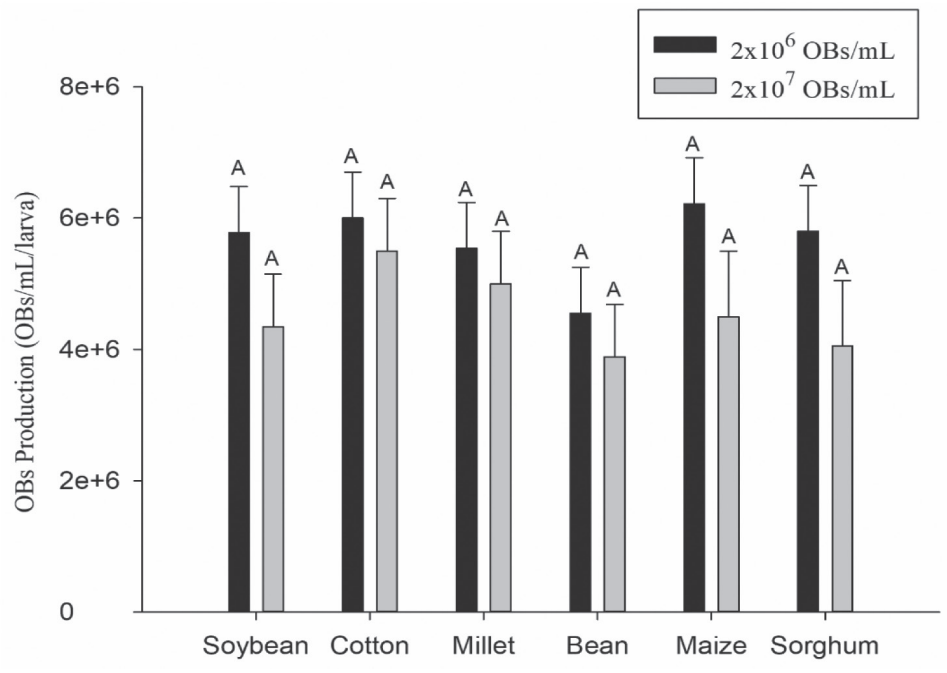

Figure 5. OBs production (OBs/mL/larva) ( \pm SE) of $S$. frugiperda $2^{\text {nd }}$ instar fed with soybean, bean, corn, millet and sorghum leaves in two concentrations of SfMNPV-6NR $\left(2 \times 10^{6}\right.$ and $\left.2 \times 10^{7} \mathrm{OBs} / \mathrm{mL}\right)$. Columns followed by the same upper and lower-case letters do not differ statistically between host plants and virus concentrations, respectively, by the Tukey test $(P=0.05)$. 
In conclusion, a considerable effect of the host plant on the infectivity of SfMNPV-6NR in $S$. frugiperda was demonstrated, especially for the cotton plant. These results, confirm the complexity of the tritrophic interaction between plant, insect and virus. The influence of the host plant on the insectpathogen interaction may depend of variables related to the insect, pathogen and plant, such as the chemistry composition of the host plants and the effect of their secondary compounds on the pathogen. All these factors must be considered in a context of integrated pest management. However, more field trials should be performed to evaluate the abiotic effects on this interaction.

\section{Conclusions}

A deleterious effect was demonstrated of the host plant on the infectivity of the virus of SfMNPV 6-NR in $S$. frugiperda, especially for the cotton plant.

The host plant affected differentially the biology of the host whenever infected by the pathogen, as larval weight and pupae weight. These results confirm the complexity of the tritrophic interaction among plant-insect-pathogen. All these factors must be considered in a context of the integrated pest management.

There was no effect of the host plant on the OBs virus production.

\section{Acknowledgments}

Embrapa Milho e Sorgo and Arthur Bernardes Foundation (Funarbe) for the financial support for this work.

\section{References}

ADAMS, J. R.; McCLINTOCK, J. T. Baculoviridae, nuclear polyhedrosis viruses: part 1: nuclear polyhedrosis viruses of insects. In: ADAMS, J. R.; BONAMI, J. R. (Ed.). Atlas of invertebrate viruses. Boca Raton: CRC Press, 1991. Chapter 6, p. 87-180.

BARTLETT, M. S. Properties of sufficiency and statistical tests. Proceedings of the Royal Statistical Society, v. 160, n. 901, p. 268-282, 1937.

DOI: $10.1098 /$ rspa.1937.0109.

BRASIL. Ministério da Agricultura, Pecuária e Abastecimento. AGROFIT: sistemas de agrotóxicos fitossanitários. Brasília, DF, c2003. Available in: <http:// agrofit.agricultura.gov.br/agrofit_cons/principal_agrofit_ cons>. Access in: 12 jan. 2018.

CORY, J. S.; HOOVER, K. Plant mediated effects in insectpathogen interactions. Trends in Ecology \& Evolution, v. 21, n. 5, p. 278-286, 2006.

DOI: $10.1016 /$ j.tree.2006.02.005.

CRUZ, I.; FIGUEIREDO, L. M. C.; SILVA, R. B.; FOSTER, J. E. Efficiency of chemical pesticides to control Spodoptera frugiperda and validation of pheromone trap as a pest management tool in maize crop. Revista Brasileira de Milho e Sorgo, v. 10, n. 2, p. 107-122, 2010. DOI: $10.18512 / 1980-6477 /$ rbms.v9n2p107-122.

FARRAR, R. J. R.; RIDWAY, R. L. Host plant effects on the activity of selected nuclear polyhedrosis virus against the corn earworm and beet armyworm (Lepidoptera: Noctuidae). Environmental Entomology, v. 29, n. 1, p. 108-115, 2000.

DOI: 10.1603/0046-225X-29.1.108.

GRZYWACZ, D. Basic and applied research: Bauclovirus. In.: LACEY, L. A. Microbial control of insect and mite pests. London: Academic Press, 2017. p. 27-46.

DOI: 10.1016/B978-0-12-803527-6.00003-2.

GREENE, G. L.; LEPPLA, N. C.; DICKERSON, W. A. Velvetbean caterpillar: a rearing procedure and artificial 
medium. Journal of Economic Entomology, v. 69, n. 4, p. 487-488, 1976. DOI: 10.1093/jee/69.4.487.

HAASE, S.; SCIOCCO-CAP, A.; ROMANOWSKI, V. Baculovirus insecticides in Latin America: historical overview, current status and future perspectives, Viruses, v. 7, n. 5, p. 2230-2267, 2015.

DOI: $10.3390 / \mathrm{v} 7052230$.

HERNIOU, E. A.; ARIF, B. M.; BECNEL, J. J.; BLISSARD, G. W.; BONNING, B.; HARRISON, R.; JEHLE, J. A.; THEILMANN, D. A.; VLAK, J. M. Family Baculoviridae. In: KING, A. M. Q.; ADAMS, M. J.; CARSTENS, E. B.; LEFKOWITZ, E. J. (Ed.). Virus taxonomy: classification and nomenclature of viruses: ninth report of the International Committee on Taxonomy of Viruses. Amsterdam: Elsevier Academic Press, 2012. p. 163-173.

DOI: 10.1016/B978-0-12-384684-6.00013-6.

HOOVER, K.; WASHBURN, J. O.; VOLKMAN, L. E. Midgut-based resistance of Heliothis virescens to baculovirus infection mediated by phytochemicals in cotton. Journal of Insect Physiology, v. 46, n. 6, p. 9991007, 2000.

DOI: 10.1016/S0022-1910(99)00211-5.

MONOBRULLAH, M.; SAHNKAR, U.; BHARTI, P.; GUPTA, R. K.; KAUL, V. Effect of host plant on the in infectivity of SMNPV to Spodoptera litura (Fabricius) (Leipidoptera: Noctuidae) larvae. Journal of Asia-Pacific Entomology, v. 10, n. 2, p. 151-155, 2007.

NAVON, A.; ZUR, M.; ARCAN, L. Effects of cotton leaf surface alkalinity on feeding of Spodoptera littoralis larvae. Journal of Chemical Ecology, v. 14, n. 3, p. 839844, 1988. DOI: 10.1007/BF01018777.

PIUBELli, G. C.; MOSCARDI, F.; CAMPO, C. B. H. Interactions among insect-resistant soybean genotypes extracts with populations of Anticarsia gemmatalis Hübner (Lepidoptera: Noctuidae) susceptible and resistant to its nucleopolyhedrovirus. Anais da Academia Brasileira de Ciências, v. 81, n. 4, p. 861-871, 2009.

DOI: $10.1590 /$ S0001-37652009000400021.
PLYMALE, R.; GROVE, M. J.; COX-FOSTER, D.; OSTIGUY, N.; HOOVER, K. Plant-mediated alteration of the peritrophic matrix and baculovirus infection in lepidopteran larvae. Journal of Insect Physiology, v. 54, n. 4, p. 737-749, 2008.

DOI: 10.1016/j.jinsphys.2008.02.005.

RAYMOND, B.; HAILS, R. S. Variation in plant resource quality and the transmission and fitness of the winter moth, Operophtera brumata nucleopolyhedrovirus. Biological Control, v. 41, n. 2, p. 237-245, 2007.

DOI: 10.1016/j.biocontrol.2007.02.005.

RAYMOND, B.; VANBERGEN, A.; PEARCE, I.; HARTLEY, S. E.; CORY, J. S.; HAILS, R. S. Host plant species can influence the fitness of herbivore pathogens: the winter moth and its nucleopolyhedrovirus. Oecologia, v. 131, n. 4, p. 533-541, 2002.

DOI: $10.1007 / \mathrm{s} 00442-002-0926-4$.

RAVISHANKAR, B. S.; VENKATESHA, M. G. Effectiveness of SINPV of Spodoptera litura (Fab.) (Lepidoptera: Noctuidae) on different host plants. Journal of Biopesticides, v. 3, n. 1, p. 168-171, 2010.

REDMAN, E. M.; WILSON, K.; CORY, J. S. Trade-offs and mixed infections in an obligate-killing insect pathogen, Journal of Animal Ecology, v. 85, n. 5, p. 1200-1209, 2016. DOI: 10.1111/1365-2656.12547.

ROODE, J. C.; PEDERSEN, A. B.; HUNTER, M. D.; ALTIZER, S. Host plant species affects virulence in monarch butterfly parasites. Journal of Animal Ecology, v. 77 , n. 1, p. $120-126,2008$.

DOI: $10.1111 / \mathrm{j} .1365-2656.2007 .01305 . x$.

ROSA, A. P. S. A. da; BARCELOS, H. T. Bioecologia e controle de Spodoptera frugiperda em milho. Pelotas: Embrapa Clima Temperado, 2012. 30 p. (Embrapa Clima Temperado. Documentos, 344).

SHAPIRO, S. S.; WILK, M. B. An analysis of variance test for normality (complete samples). Biometrika, v. 52, p. 591-611, 1965.

DOI: 10.1093/biomet/52.3-4.591. 
SHIKANO, I.; SHUMAKER, K.; PEIFFER, M.; FELTON, G. W.; HOOVER, K. Plant-mediated effects on an insect-pathogen interaction vary with intraspecific genetic variation in plant defenses. Oecologia, v. 183, n. 4, p. 1121-1134, 2017. DOI: 10.1007/s00442-017-3826-3.

VALICENTE, F. H. Consumo foliar da lagarta do cartucho do milho, Spodoptera frugiperda (J. E. Smith, 1797) infectada com vírus de granulose ou de poliedrose nuclear. Anais da Sociedade Entomológica do Brasil, v. 17, n. 2, p. $349-357,1988$.

VALICENTE, F. H.; TUELHER, E. S.; PENA, R.

C.; ANDREAZZA, R.; GUIMARÃES, M. R. F. DOI: 10.1016/j.jip.2012.07.010.
Cannibalism and virus production in Spodoptera frugiperda (J.E. Smith) (Lepidoptera: Noctuidae) larvae fed with two leaf substrates inoculated with Baculovirus spodoptera. Neotropical Entomology, v. 42, n. 2, p. 191-199, 2013.

DOI: $10.1007 / \mathrm{s} 13744-013-0108-6$.

VIEIRA, C. M.; TUELHER, E. S.; VALICENTE, F. H.; WOLFF, J. C. Characterization of a Spodoptera frugiperda multiple nucleopolyhedrovirus isolate that does not liquefy the integument of infected larvae. Journal of Invertebrate Pathology, v. 111, n. 2, p. 189$192,2012$. 